\title{
THE MANAGEMENT POLICY OF ASPHALT BUTON MINE IN REFORMATION ERA IN THE POLITICAL ECONOMY PERSPECTIVE IN BUTON REGENCY INDONESIA
}

\author{
Rahmawati ${ }^{*}$, Candidate Doctor \\ Zauhar Soesilo, Mardiyono, Santoso Bambang, Lecturers \\ Doctoral Program of Administrative Science, Faculty of Administrative Science, \\ University of Brawijaya, Malang, Indonesia \\ *E-mail: rahmawati14fia@gmail.com
}

\begin{abstract}
The purpose of this research is to describe the management policy of Asphalt buton mine in Reformation Era in the political economy perspective of Buton Regency, Indonesia. Decentralization of mining management caused many problems, authority distribution in central and local government still keep many problems unsolved. Because of that, the government conducted intervention in giving mining license in Indonesia. State needed take action rationally in building business climate in Buton Regency, especially in asphalt buton mining sectors through rational policies.
\end{abstract}

\section{KEY WORDS}

Policy, asphalt mine, government, rent, regency, descriptive qualitative, reformation period.

Management and utilization of natural resources has been defined through the constitution 1945 chapter 33 which the main purpose is to prosper the whole of Indonesian people. Mandatory of constitution 1945 is become the base foundation to issuing mining policy such as constitution No.11 1967 about mining principle of mineral and coal, later replaced by constitution No.4 2009 about mining of mineral and coal. According to Saleng (2007), constitution No.4 2009 about Mining of mineral and coal is the consequences of constitution number 332004 about central government and local government finance balancing which is arranged in government regulation number 252000 about the government authority of regency and province as Autonomy area. Later, the regulation totally changed by issuing constitution No.23 2014 about Autonomy area and decided that Province took over the Regency authority.

In the context of policy in reformation era, decentralization of utilization mining management caused many problems, authority distribution in central and local government still keep many problems unsolved effectively until today, such as overlap authority. At least, there are about 10.640 issued new mining licenses. Government issued about $50 \%$ from total mining license. Later, there are problems came from (Indonesia Mining Association (IMA): 2015) related to this license.

Because of the problems mentioned above, the government conducted intervention in giving mining license in Indonesia. This condition clearly described the important role of the government in many national economic sectors (Solichin Abd. Wahab: 1999). Being dominant of the mining policy above would become natural and make sense because the government have more right to manage mine resources that exist, as mentioned in chapter 33 verse 2 and 3 about expression "dominated by the state "and the words". The utilization is to prosper all the Indonesian people "initiatively to share with investors who oriented in the importance of earth and water and all natural resources. This illustration, clearly described the importance of the government role to aim at economic and business sectors, which is relevantly to use in describing the situation happen in Indonesia. (Sholichin Abd. Wahab: h. 13, 1999).

Domination through the contribution of mining policy is one of interfere of government that need to be supported as long as the government could play the role fairly and responsibly, however if the government are unable to do it right, automatically it would give impact to the country prosperity. In political economic approach described that government 
play in secondary role, they play as the instrument or as institution for individual or groups to achieve personal purpose. Caporaso and Levine (1992). As Wolin feared that when government as instrument were unable to take control of individual interest (market, economy), so the position of the government would be derivative. Caporaso and Levin (1992).

In Buton regency, the government took an importance role in mining sectors of asphalt Buton, the role was issued in constitution No. 232014 about Local Government, taking over government authority from the regency to central government and province in managing forestry, maritime, energy and other matters. On the other hand, those came some consequences such as; inharmoniously policy, overlap, inconsistent, social conflict, that implied to the low of Genuine Local Income and prosperity of the people in Buton regency.

The weak of management policy of asphalt buton in reformation era has changed significantly compared with policy in the previous era. The weak of utilization of asphalt buton was not developing the local economy: 2011 Local income for asphalt buton mine was Rp. 6.354.605.250,-, year 2012 Rp. 8. 146.549. 567 and year 2013 Rp. 10. 115. 291. 794. ( source PAD Mining Service Buton Regency 2014), and the low level of people prosperity, poverty level in year 2013 in position 67,55 percent, and in 2014 increased to 68,07 percent (BPPS, Kab. Buton,2016).

Although this country has been changed significantly from centralistic to decentralization (local autonomy), however that does not give guarantee to raise up the people prosperity in Buton regency until today. Many monopoly opportunity and economic sector governance for certain actors become historical notes and hard work beginning for government in reformation era especially in Buton Regency, so Robison and Hadiz, (197: 2004) stated that government/state in reformation era needed to do a lot of changes institutionally into creation of democracy institutional and decentralization significantly. Therefore, it can conclude that democracy is as a leader to open the political system transparently.

For that reason, government, which get involved in managing economy sectors directly, should become a mediator in managing market activities Bremmer (2011). That is why government involvement through mining policy presupposing state power to control the market place in mining sectors. In considerable study of political economy, state often referable as unit of analysis because state always get great intention portion from political economy expert for long time ago.

The understanding about political economy in mining sectors in Indonesia related to the background of its institution. State is an entity that has direction authority of economy and politic life. Hence, the importance of state in implementing regulation adjust political economy activities. The existence of various regulations that settle about mining management is always appropriate with ideology view of the state implementation when they issued the policy. As stated by Solichin Abdul Wahab,(1999), that environment factor influenced the state power (especially in political environment) through business sector. We can see the effects from the impact through strategic decision taking, especially in long range planning in an infestation decision.

In the similar thinking plot, some study stated by the experts such as Lauterbach (1966) in some state in Latin America, Davis (1970), in Chili and Lauter (1970) in Turkey showed that there are many strong correlation between conditions of economy, politic, and strategy planning function ( trade extension/infestation) in a state's business sectors Solichin Abdul Wahab (34.1999). Relevance between government importance and business world (rente) as an actor that play economy/market activity. State importance by Wolin in Coraso and Levine (446: 1992), described that a state get position as instrument in derivative way did not have its own logic, did not have motivation energy sources using outside from economy, identically as dependent variable in economy. So, Krasner (1978) and Skocpol (1983) stated that state should be free from any external influences or society influences, it means that state should have autonomy character, so there wouldn't influence outside itself contained. However, market or rent in political economy context assumed as market group to 
get profit that some people enjoy it because they could get privilege/protection from certain traders to seek the rights of the government. (Hudiyanto, 21: 2014).

\section{METHODS OF RESEARCH}

This research method was descriptive qualitative (Moleong, 2007), by considering to the need of the research study to interpret description of a social phenomenon, that's policy portrait of reformation era in the authority of asphalt mining management in Buton Regency. Chosen period hopefully able to accommodate the changes policy through asphalt buton management in Buton regency. There were three ways to collect the data: phenomenon, documents and deeply interview with some informants in purposive technic. The researcher interviewed functionaries, local society, mine experts and investors of asphalt Buton mining. The researcher got the phenomenon by recording any activities of the actors whether individuals or organization in term of government relation vertically or horizontally, cooperation relation between government institution, private later He obtained the data from data record, that is fidelity and structure. However, the researcher obtained the document sources from the phenomenon or events in relevant documents. They are like Letter of central and local government decision, other secondary data such as: strategic plan, manual of the implementation of mining management policy, event reports and collaborate with some local or state which get involved in management policy of asphalt mining, and some pictures of the activity in management asphalt buton.

\section{RESULTS OF STUDY}

Many monopoly opportunities and governance economy of sector player become historical notes and become beginning of hard work for the government in reformation era. In this period the government conducted many changes institutionally into democracy institutional creation and decentralization significantly Robison and Hadiz, (197: 2004). Related to the statement above, it concluded that management policy of asphalt buton mining in political economy perspective could be seen on two things, there were state involvement and rent seeking.

State with political economy perspective has important involvement in secondary term, a state assumed not as an active actor but as instrument for intentions and importance through regulation Caporaso \& Levine (445: 1992).

Replacement of state position in managing asphalt buton categorized as regulator in asphalt buton management. The government was still controlling the management of asphalt buton in reformation era, they played dynamically in mining management policy especially asphalt buton.

Asphalt buton management policy was not only in exploration and exploitation aspects but also in diversification policy aspect (diversification products), and asphalt buton environment conservation. We can see from the picture mapping utilization mining area issued by South East Sulawesi province in acquire preservation and roads need about 1,2 million tons asphalt.

Policy of mining diversification by government purposed to supply asphalt buton utilization so it would not exploited only to raw material but could give multi product so, potential deposit asphalt buton would not greatly exploit. This policy way conducted through deposit supply guarantee of asphalt buton and optimizing of asphalt buton production tobe more multi product. It hoped the utilization of asphalt buton be more effective and efficient.

Besides, government as the player of asphalt buton potential as mandated in constitution 1945 chapter 33 verse 2 and 3, about words "governance by state" and "utilization to prosperous Indonesia people" become initiative from state to keep sharing with many investors who have orientation of profit importance. Local law (perda) No. 172013 about founding local company asphalt buton mining management, and interlacing cooperation with any foreign countries through socialization about potential prospect of asphalt buton like in Tiongkok, Beijing, and China by Buton regency government in year 2014. On the other hand, by issuing policy constitution No.23 2014 about Local Government, 
leaving controversy and new problem through inconsistent policy in managing asphalt buton mining in Buton Regency, as stated by ED:

"Recently we had been doing many socialization activities and interlacing communication with many players especially the investors from foreign country (Tiongkok), in collaborating for potential utilization asphalt buton, moreover we issued policy through Local Law No.17 2013 about founding Local Company (Perusda) management of asphalt buton mining, however this policy had not been running optimal because since the issue of policy constitution No. 232014 from central government so the relation had been made was unfinished, and inharmonious communication with government disturbed activity of management asphalt buton in local area." Interview, 24 November 2016.

There are 2 matters of State involvement in managing asphalt buton mining in reformation era: First, State get involved directly in founding capitals to invest their money in managing asphalt buton through some local companies. Second, State get involved indirectly through the planning, regulation formula and implementation policy in local area, but in the other side it caused controversy and new problem in local policy (inconsistent).

The involvement of businessman in asphalt buton mining sectors become the point in reformation era, different with new order era where the involvement private sectors in asphalt buton management were very weak but in reformation era the government has been involving the private in managing asphalt buton through mining in Buton Regency that can be shown from the table:

Table 1 - Companies involved in asphalt buton management

\begin{tabular}{|l|l|l|l|l|}
\hline No & Name of the companies & Mining location & Wide (Ha) & Reserve (Ton) \\
\hline 1 & PT. SARANA KARYA & Kabungka Lawele & 318.526 & 38.223 .120 \\
& & & 100 & 30.000 .000 \\
\hline 2 & PT. OLAH BUMI EL CIPTA & Waesiu/Rongi/ Sampolawa & 97,69 & 3.516 .000 \\
& & Kabungka & 1.056 .425 & - \\
& & Lawele & 100 & - \\
\hline 3 & PT. TIMAH (Persero) Tbk & Lawele & $1.182,36$ & - \\
& & Blok Ulala & $1.928,20$ & - \\
& & Lawele & $1.171,36$ & - \\
\hline 4 & PT. YUMAN JAYA TAMA & Kabungka/ Pasarwajo & 50 & 15.000 .000 \\
\hline 5 & PT. PUTINDO BINTECH & Kabungka/ Pasarwajo & $1.650,38$ & 11.760 .000 \\
\hline
\end{tabular}

Source: Distaben Buton Regency, 2016.

From the data above showed that the Mining and energy Service of Buton Regency is still restrictive until today, starting from 2001 asphalt production reached into 200.000 tons per year. However deposit asphalt reached until 650.000 tons well-kept spread out 70.000 hectare in some pointed location, such as; Kabungka Lawele, Waesiu/Rongi/Sampolawa, Blok Ulala and Pasarwajo.

However for the involvement of utilization asphalt buton according Mining and energy Service South East Sulawesi that there are 41 mining trade license consist of: 33 mining trade license for operation production and 8-exploration mining trade license.

The involvement utilization asphalt buton from State to private was great, so it hoped that business relation term between State and private in asphalt buton management could run by its portion, however expectedly there are some businessman and government side conducted open negotiation about the transaction of State natural sources share. As explained by $\mathrm{BC}$ one of the head of mining and energy service explained as follow:

"Transaction and negotiation about fight of state resources has happened long time ago in Buton regency especially for land management of asphalt buton. Since there has greatly open land, issuing license by negotiating about the profit with functionaries so, they issued many asphalt buton licenses but because of bad processing so some mining licenses started to manage orderly, it was not more than 10-20 years." (Deeply interview, 1 December 2016). 
Based on the explanation above, the researcher observed that management of asphalt buton has not been running well all this time because state policy was still weak in controlling mining license, businessman assumed to share state resources whereas rent seeking become prominent in business relation, those actions conducted openly in democracy era that increased corruption along this era. As stated by LD that:

"there were intervention from national trader of asphalt mining who owned asphalt mining license in BUton Regency through management policy of asphalt buton, if the management asphalt buton specifically involved monitoring from central government, province and local area they would tried to prevent it. So, although Buton regency government socialized and tried hard to collaborate with local trader to produce asphalt buton, the central government has not been giving positive respond through management policy of asphalt buton." (Deeply Interview, 1 December 2016).

Rent seeking in reformation era took an important place to influence regulation asphalt buton management; many freed of mining license, limitation of asphalt buton utilization become a problem unsolved until today in Buton regency.

\section{DISCUSSION OF RESULTS}

There were two aspects in management asphalt buton from political economy perspective, such as state Involvement and rent seeking.

State involvement in managing asphalt buton in reformation era can be seen from two aspects, such as: First, the state participated directly by its money to invest on management of asphalt buton through some local companies. Second, the state participated indirectly through planning, regulation formula and policy implementation in local area.

This research finding similar with Solichin Abdul Wahab (1999) statement, said that there is a relationship with environment in business sector. It effected to the term of strategy decision taking, especially in long-range planning such as infestation decision. Later, in study of Davis in Chili (1970), described that a question for some functionaries like how long the distance from formal planning to market place is. The answer was a state through its political position was able to support the business movement that assumed can give some profit or even loss. From some opinions above, showed that state involvement in economic activities gave less benefit, later the state would be in market spectrum by extreme ideology aim to capitalism in a real world. As happened in Cuba. Ian Bremmer (46: 2011).

For that reason, the state involvement hoped able to manage economic activities as a mediator in market activities lan Bremmer (2011), if it happen in management of asphalt buton mine the state would become neutral institution by using its independent ability from social factors especially in economic factors lan Bremmer (448: 2011).

So that, the state should have autonomy rights, it means that the state is free from external influence, like: (first), a state should be free and able to "win to fight" from civilization pressures, because a state have its own purposes through policies. (Second), the action of a state is uninfluenced power from any groups or certain coalition. (Third), a state should reject or restrain outside pressure especially in policy taking (caporaso \& Levine, 450: 1992).

An independent and strong state implicitly assumed able to play the role and respond other intention as long as not disturbing state purpose to increase its state prosperity.

State authority in economic extension asphalt buton mining investment is necessary to do as long as the state be able to play fairly and able to neutralize investment through rationally regulation.

Democracy pressured through decentralization made private get access and opportunity from government to get involved in managing asphalt buton. It proved from the big three company from private, they are: PT. Olah Bumi Elcipta, PT. Yuman Jaya Tama, PT. Putindo Bintech which is having land and deposit asphalt production has been distributed abroad. The private involvement in managing asphalt buton mining is not only in production and in distribution but that assumed there were businessman and government functionaries conducted openly negotiation to make transaction in sharing state resources and participated in policy intervention. Rent seeking activity become an important role in business relation and 
the activity happened openly in reformation era, in the end it caused corruption, cut throat competition.

Actually, they should anticipated and detected when economic failure happened in new order era, where the government gave greatly opportunity to the market place, although there happened higher growth compared with other ASEAN countries. However, historical facts proved that the activities in new order era infected political economic stigma since middle decade 1980's. There were great distortion happened in social economic sectors and this peak was in 1990's, along with the increase of capital investment flow in many sectors caused the stumble of new order era, as the result of corruption, nepotism practical, this moment even happened in the best economic achievement in 1992. (Solichin Abdul Wahab: 1999).

Based on the previous experience hoped that rent seeking in economic sectors especially in managing asphalt buton mining shouldn't practice freely, the involvement of regulation intervention should be minimized so the opportunity of rent seeking wouldn't be wider which effected to new distortions.

As stated by Didik J. Rachbini, (2006) that in political economic, rent seeking was getting income by manipulated license and power in business. Traders got profit by negative way in the market place. They used power and authority to influence the market place which caused distortion. Economic rent seeking would happen when a trader or a company took advantage or value which didn't get compensation from others by doing manipulation work or business environment. Manipulation in work environment also happened because of monopoly struggle on role play or regulation.

There was similar opinion with Olson in Yustika (107: 2012) that rent seeking in political economic view tends to negative stigma because it can create negotiation opportunity as short cut action which effect colossal then caused decision making run very slow and the economy in the end could not respond fast through changes and new technologies.

From the statement above, rent seeking seemed like struggle profit obtain which tend to inflict a financial loss, corruption opportunity would be wider, by this condition a state would be susceptible to build clean government indirectly state and nation in unprofitable position. Most executives should realize and understand that the main target of trade institution was not only profitability and growth, but also image, image building which was the target from long-term purpose in every business institution. Positive image would become precious valuable "asset" for corporate world if they want to pay attention to it. (Rumokoy N.K in Building Strategy journal: 2010).

\section{CONCLUSION}

From the references above, it expected that government should be able to prevent the spread out of rent seeking like: monopoly practice, intervene regulation that referred to corruption and nepotism indirectly gave impact to the inflict government loss in a long term.

Management policy of asphalt buton mining in political economic perspective included two aspects; they are state involvement and rent seeking. An independent state/country in managing through asphalt buton should be harmony and distinctly. It does not mean that a state is strict, closing faucet for investor involved in mining management. State needed take action rationally in building infestation climate in Buton Regency, especially asphalt buton mining sectors through rational policy.

\section{REFERENCES}

1. Abdul Wahab Solichin. 1999. Ekonomi Politik Pembangunan (Bisnis Indonesia era Orde Baru dan ditengah krisis moneter). Penerbit Danar Wijaya. Brawijaya Universitas Press.

2. Caparoso, J.A. \& D.V.Levine. 1992. Theories of Political Economy. New York: Cambridge University Press.

3. Davis, Stanley M. 1970. The Politics Organizational Undevelopment: Chile, Industrial and Labour Relations Review, October. 
4. Dunn, William N.. 2000. Pengantar Analisis Kebijakan Publik. Edisi Kedua.

5. Cetakan ketiga. Gadjah Mada University Press.

6. Ian Bremmer. 2011. Akhir Pasar Bebas (The End Of The Free Market). Penerbit Gramedia Pustaka Utama Kompas Gramedia. Jakarta.

7. Kotler, Philip. (2000). Manajemen Pemasaran. Jakarta : Prehallindo.

8. Moleong, Lexy. 2007. Metodologi Penelitian Kualitatif (Edisi Revisi). Penerbit Remaja Rosdakarya. Bandung.

9. Netting, F. Ellen, Petter M. Kettner dan Steven L. McMurtry (1993), Sosial Work Macro Praktice, New York: Longman.

10. Norton, Alan, 1997, International Handbook of Local and Regional Government: A Comparative Analysis of Advanced Democracies, Edward Elgar, UK Lyme, US.

11. Rondinelli, Dennis A. 1990. Decentralizing Urban Development Programme. USA.

12. Robison, Richard and Vedi R. Hadiz.2004. Reorganizing Power in Indonesia: The Politic of Oligarchy in an Age of Market. London and New York: Routledge.

13. Robison, Richard and Vedi R. Hadiz.2004. Reorganizing Power in Indonesia: The Politic of Oligarchy in an Age of Market. London and New York: Routledge.

14. Rachbini, Didik J. 2006. Ekonomi Politik dan Teori Pilihan Publik. Bogor: Ghalia Indonesia.

15. Sajuti Thalib, (1971). Hukum Pertambangan Indonesia. (Bandung, Akademi Geologe dan Pertambangan).

16. Smith, B.C. 1985. Decentralization: The Territorial Dimension of The State. George Allen \& Urwin: Sydney Australia.

17. Suyanto, Bagong. 1996. Kemiskinan dan Kebijakan Pembangunan. Aditya Media. Yokjakarta.

18. Staniland, Martin. 2003. Apakah Ekonomi Politik Itu? Sebuah Studi Teori Sosial dan Keterbelakangan. Jakarta: PT Raja Grafindo Persada.

19. Scoot, Richard W. 2008. Institutions and Organization: Ideas an Interest. Los Angeles, London, New Delhi, Singapore: Sage Publication. Third Edition. 266.hal.

20. Salim HS, 2012, Hukum Pertambangan di Indonesia, PT. Raja Grafindo Persada, Jakarta.

21. Yustika, Ahmad Erani. 2012. Ekonomi Kelembagaan Paradigma, Teori, dan Kebijakan. Penerbit Erlangga: Jakarta. 